\title{
Prostaglandin Analog and Peripheral Anterior Synechia
}

\author{
Osama M. Badeeb, MD, FRCS(C) \\ Department of Ophthalmology, Faculty of Medicine \\ King Abdulaziz University, Jeddah, Kingdom of Saudi Arabia \\ obadeeb@yahoo.com
}

\begin{abstract}
The purpose of this document is to report peripheral anterior synechia in three patients on prostaglandin analog eye drops. This report includes a clinical eye examination of a 54-year old female with primary chronic angle closure glaucoma, a 63-year old male with primary open angle glaucoma and a 64-year old male with exfoliation open angle glaucoma after 6 months of using Latanoprost drop in cases (1 and 2) and Bimatoprost drop in case (3). Peripheral anterior synechia developed in all patients, in spite of open angle in cases ( 2 and 3 ) and almost quiet anterior chamber. This did not progress after stopping the medication. Precaution should be taken when using these eye drops in patients with narrow angle glaucoma.
\end{abstract}

Keywords: Latanoprost, Bimatoprost, Peripheral anterior synechia, Glaucoma.

\section{Introduction}

Latanoprost (Xalatan, Pharmacia, Pea Pack, New Jersey, USA) and Bimatoprost (Lumigan, Allergan, Inc., Irvine, CA) are prostaglandin F2 $\alpha$ analogs. Since Latanoprost introduction in 1996, several side effects have been reported to occur with it and with other prostaglandin analogs. There have been no reported cases of peripheral anterior synechia (PAS) in spite of reported cases of anterior uveitis ${ }^{[1,2]}$.

At present no reported cases, and this could be the first time that PAS is reported to occur with Latanoprost and Bimatoprost.

Correspondence \& reprint request to: $\quad$ Dr. Osama M. Badeeb

P.O. Box 512, Jeddah 21422 Saudi Arabia

Accepted for publication: 28 September 2007. Received: 01 July 2007. 


\section{Case 1}

A 54-year old Caucasian female was referred to the glaucoma clinic at King Abdulaziz University Hospital (KAUH) in April 2002. She was diagnosed with primary chronic angle closure glaucoma (PCACG) in both eyes (OU) and uncontrolled glaucoma with maximum tolerated medication in the right eye (OD). She was on Cosopt (Dorzolamide / Timolol maleate) drops (tid) and Latanoprost, once daily to OU. There was no history of uveitis.

Her best, corrected vision was 0.8 OD and 1.0 left eye (OS). Pupils were normal in size, reactive to light; and the right one showed relative afferent pupillary defect. Slit Lamp (SL) examination revealed white conjunctiva, clear cornea, moderately deep and clear anterior chamber (AC), flat normal iris, and clear lens OU. The intraocular pressure (IOP) was $25 \mathrm{mmHg}$, OD and $15 \mathrm{mmHg}$, OS. Gonioscopy revealed bilateral narrow angle grade (II) $360^{\circ}$ (Shaffer's classifications), with no peripheral anterior synechia (PAS). Cup/disc ratio was OD 0.95 and OS 0.7.

She was diagnosed as having advanced PCACG and underwent trabeculectomy in OD and continued on the above medications to OS.

In October 2002, SL examination of OS showed dilated conjunctival vessels, peaked pupil, and atrophic round iris lesion about $1 \mathrm{~mm}$ in diameter close to its periphery at 12 o'clock position (Fig. 1). Occasional cells were seen in the AC, which was moderately deep except at 12 o'clock position. IOP was $16 \mathrm{mmHg}$. The angle was narrow (grade II) with the presence of PAS at 12 o'clock (Fig. 2). Latanoprost was replaced by Alphagan (Brimonidine $0.2 \%$ ) drops BID and the patient was closely followed without developing further PAS and with controlled IOP until presently.

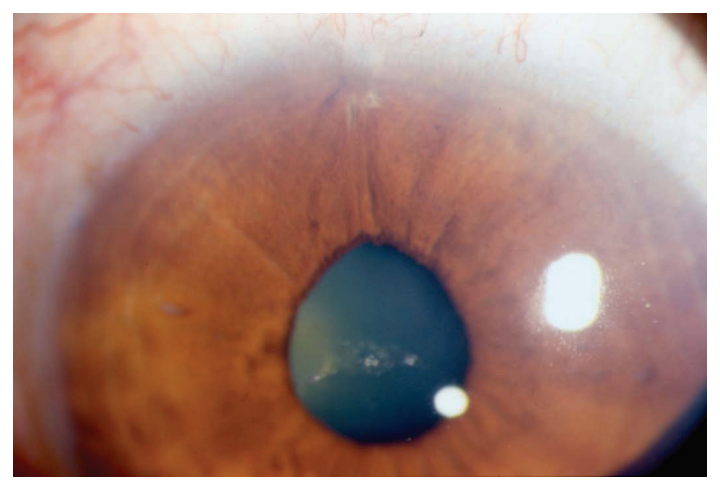

Fig. 1. Showing peaked pupil and PAS at 12 o'clock. 


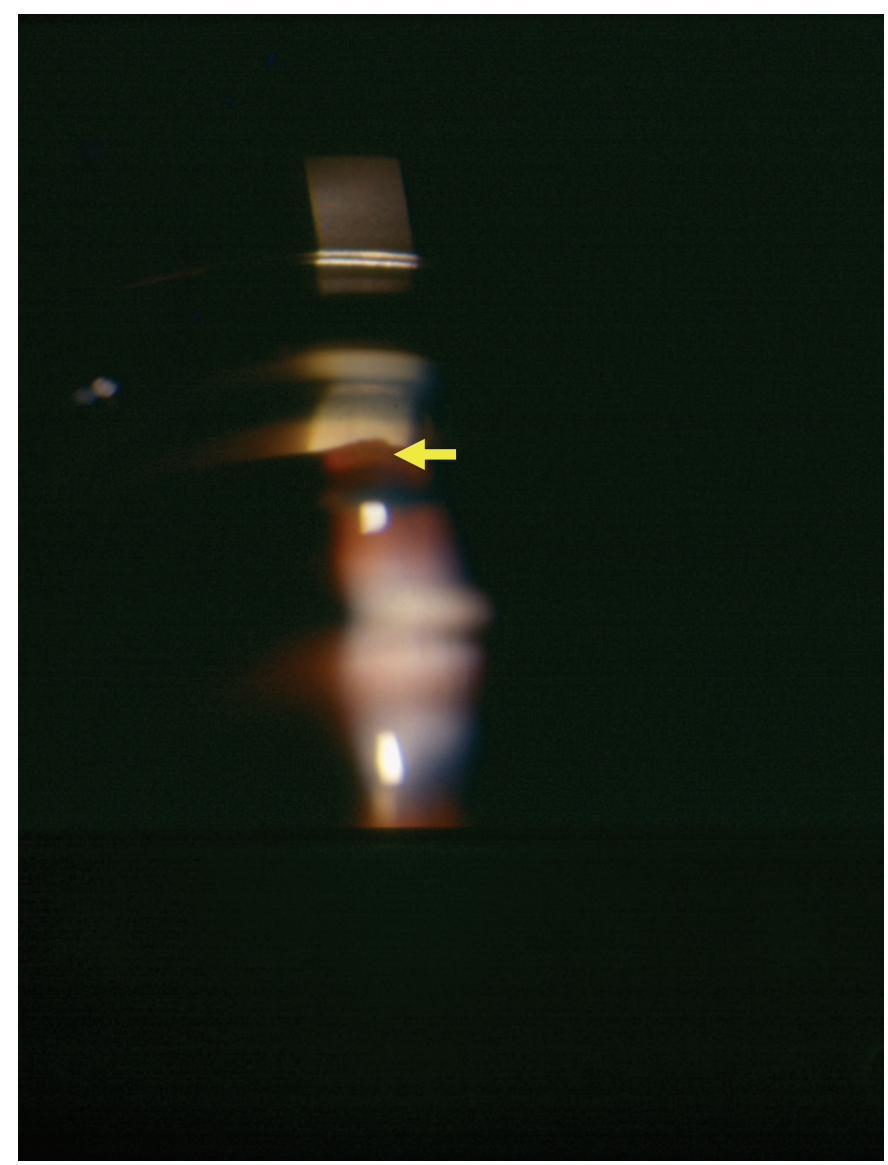

Fig. 2. Gonioscopical picture showing the PAS at 12 o'clock (arrow).

\section{Case 2}

A 63-year old Caucasian man was diagnosed in January 2000 of having primary open angle glaucoma (POAG) in both eyes. He had combined phaco-trabeculectomy in the right eye. In January 2001, he came to the glaucoma clinic at KAUH complaining of a decrease of vision OU. There was no history of uveitis. He was on Betagan (Levobunolol 0.5\%) drops twice per day to OU and Pilocarpine 4\% drops (qid) to OS.

His best, corrected vision was $0.4 \mathrm{OD}$ and $0.5 \mathrm{OS}$. The right pupil was normal in size and reactive to light; the left one was meiotic, regular, round and not reactive to light. SL examination revealed white 
conjunctiva, clear cornea OU and shallow bleb at 12 o'clock OD. Deep, quiet, $\mathrm{AC}$ and regular round pupils OU. OD was pseudophakic and mild cataract (nuclear sclerosis) of OS. IOP was $9 \mathrm{mmHg}$, OD and $19 \mathrm{mmHg}$, OS. Gonioscopical examination showed bilateral open angle grade IV $360^{\circ}$. Cup/disc ratio was 0.5 with temporal pallor OU.

Since the patient's vision diminished while he was on Pilocarpine, Pilocarpine was replaced with Brimonidine drops BID to OS and the IOP was under control for two years. In January 2003, IOP increased to 24 $\mathrm{mmHg}$ in OS and Brimonidine was replaced with Latanoprost once a day. The IOP then dropped to $16 \mathrm{mmHg}$. In June 2003, SL examination of OS showed dilated conjunctival vessels, pannus and peaked pupil at 3 and 7 o'clock. The iris showed 2 round atrophic areas about $1 \mathrm{~mm}$ in diameter each close to its periphery at the 3 and 7 o'clock positions. Occasional cells were seen in the AC which was deep except at those two positions. IOP was $16 \mathrm{mmHg}$. The angle was open (grade IV) with the presence of 2 PAS at 3 and 7 o'clock.

Cosopt replaced Latanoprost and Levobunolol and the patient's IOP was under control with no further PAS formation until the time of writing the manuscript.

\section{Case 3}

A 64-year old male patient has been followed in the glaucoma clinic at KAUH for the last 17 years. There was no history of uveitis. He was diagnosed of having exfoliation glaucoma with narrow approach open angles grade (III-IV) OU. He lost OS from glaucoma and complicated combined (cataract extraction + Trabeculectomy) and corneal graft surgeries.

Glaucoma was under control (IOP $<18 \mathrm{mmHg}$ ) in OD by Cosopt and Brimonidine drops until October 2006, when the IOP became $28 \mathrm{mmHg}$. Bimatoprost drop was added and IOP became under control $(<20$ $\mathrm{mmHg}$ ). In April 2007, the patient returned for follow-up; SL examination showed dilated conjunctival vessels, peaked pupil, and atrophic round area about $2 \mathrm{~mm}$ in diameter in the iris close to its periphery at 9 o'clock position. Occasional cells were seen in AC, which was deep except at 9 o'clock position. IOP was $16 \mathrm{mmHg}$. The angle was open (grades III-IV) with narrow approach and the presence of PAS at 9 
o'clock. Bimatoprost was replaced by Diamox (acetazolamide) tablet, with no further development of PAS and control IOP.

\section{Discussion}

PAS was never found in uncomplicated POAG and open angle glaucoma associated with exfoliation. It rarely occurs with anterior uveitis unless the eye has anatomically narrow angle in which the edematous peripheral iris comes in contact with the trabecular meshwork $^{[3]}$. The PAS in CACG usually starts as a pin point synechia reaching to the mid trabecular meshwork and then gradually expanding in width. It cannot be detected by direct SL examination of the anterior segment; it needs gonio lens to detect it, and it causes no distortion of the pupil $^{[4]}$.

The three patients reported here showed the appearance of a unique PAS after they were put on topical prostaglandin analog eye drops. The PAS was isolated, gross, and it extended anterior to Schwalbe's line into the cornea. It differs from PAS observed with CACG and anterior uveitis in that a) it occurred in both closed and open angle glaucoma; b) it occurred while the AC was relatively quiet; c) it can be seen by SL; d) it was associated with peaked pupil and segmental keratitis; e) it was associated with atrophy of peripheral iris secondary to peeling off of the anterior surface of the iris at the site of PAS; f) it did not progress after stopping the medication.

PAS to be formed in my patients the space between the trabecular meshwork and the periphery of the iris should be bridged (narrowed). Latanoprost has been reported to cause iris cyst at its periphery between its layers ${ }^{[5]}$. This could bridge (narrow) the angle space. The low-grade anterior uveitis evidenced by the presence of AC cells may cause the adhesion between the iris cyst and the trabecular meshwork.

Prostaglandin analogs were initially indicated for POAG and ocular hypertension ${ }^{[6]}$. This was broadened to include $\mathrm{CACG}^{[7]}$. Knowing that this group of medications can cause anterior uveitis, iris cyst and PAS requires that doctors utilize more care in using it in patients with narrow angle glaucoma, since it may worsen the condition. 


\section{Conclusion}

Prostaglandin analog drops are useful in controlling IOP, but it should be used with precaution in patients with narrow angle glaucoma.

\section{References}

[1] Warwar RE, Bullock JD, Ballal D. Cystoid macular edema and anterior uveitis associated with latanoprost use. Experience and incidence in a retrospective review of 94 patients. Ophthalmol 1998; 105(2): 263-268.

[2] Cano Parra J, Diaz-Llopis M. Drug induced uveitis. Arch Soc Esp Optalmol 2005; 80(3): $137-149$

[3] Grant W, Schuman J. The angle of the anterior chamber. In Epstein D., Allingham R., and Schuman J, eds. Chandler and Grant's: Glaucoma. $\left(4^{\text {th }}\right.$ ed). London: Williams \& Wilkins Co, 1997. 51-83.

[4] Lowe R., Ritch R. Angle closure glaucoma, Clinical types. In: Ritch R, Shields M, Krupin T, eds: The Glaucomas. Toronto: CV Mosby Co, 1989. 843-844.

[5] Krohon J, Hove VK. Iris cyst associated with topical administration of Latanoprost. Am J Ophthalmol 1999; 127(1): 91-93.

[6] Noecker RS, Dirks MS, Choplin NT, Bernstein P, Batoosingh AL, Whitcup SM; Bimatoprost/Latanoprost Study Group. A six-month randomized clinical trial comparing the intraocular pressure-lowering efficacy of Bimatoprost and Latanoprost in patients with ocular hypertension or glaucoma. Am J Ophthalmol 2003; 135(1): 55-63.

[7] Chew PT, Aung T, Aquino MV, Rojanapongpun P, EXACT Study Group. Intraocular pressure-reducing effects and safety of Latanoprost versus timolol in subjects with chronic angle closure glaucoma. Ophthalmol 2004; 111(3): 427-434. 


\section{القطر ات المشابهة للبروستاقلندين و التصاق القزحية

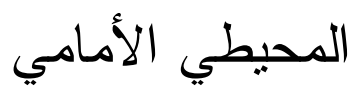

\section{أسامة محمد باديب}

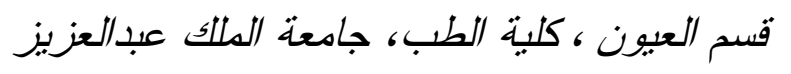

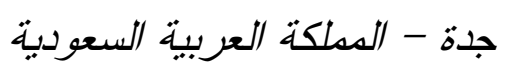

المستخلص. تم فحص ثلاثة أعبن من ثلاثة مرضى مصابين بالماء

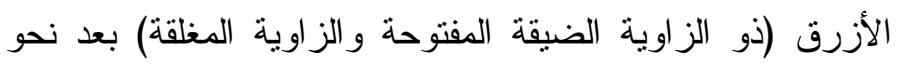
ستة أثهر من استعمالهم القطر ات المشابهة للبروستاقلندين.

أظهر الفحص السريري نكون التصاقات قزحية محيطية أمامية. هذه الالتصاقات توقفت عن التكون بعد إيقاف هذه تكان القطر ات. - ات.

يجب توخي الحذر عند استعمال هذه القطرات في المرضى الماتي المصابين بالماء الأزرق الضيق الزاوية لأنها قد تؤدي إلى تدهور المرض من جر اء تكون هذه الالتصاقات. 